(C) В.А. Черняк, В.М. Роговський, Ю.В. Нагалюк, Ю.Ю. Сіваш, М.В. Щепетов, К.К. Карпенко, 2020

УДК 616.13/.14-001.45-089.168"2014-2019"."325.1"

\title{
Результати лікування поранень магістральних судин у ході операції об'сднаних сил на Сході України за період із 2014 по I квартал 2019 року
}

\author{
В.А. Черняк ${ }^{2}$, В.М. Роговський ${ }^{1}$, Ю.В. Нагалюк ${ }^{1}$, Ю.Ю. Сіваш ${ }^{1}$, М.В. Щепетов ${ }^{1}$, \\ К.К. Карпенко \\ ${ }^{1}$ Наиіональний військовий медичний клінічний центр «Головний військовий клінічний госпіталь»; \\ ${ }^{2}$ Київський національний університет імені Тараса Шевченка, Київ
}

\section{Реферат}

Вогнепальні поранення магістральних судин залишаються актуальною і складною галуззю ангіохірургії як в лікувальному, так і в організаційному плані. За віковою категорією переважали пацієнти у віці від 21 до 3 років $(37,3 \%)$ та від 31 до 40 років $(29,4 \%)$. Найбільша доля пошкоджень припала на поранення артерій та вен, що становить $60,8 \%$. За частотою локалізації поранень магістральних судин переважають поранення стегново-підколінного сегменту - у 76,5\%. Вогнепальні поранення судин - тяжкі поранення, котрі часто поєднуються 3 травмою нервів $(23,5 \%)$, кісток $(37,3 \%)$, кісток і нервів $(25,5 \%)$, тільки м'яких тканин $(13,7 \%)$. У $47 \%$ - травма була ізольованою, у решти бійців - поєднаною. Результати лікування у 74,5\% були задовільними, у 25,5\% - завершились ампутацією кінцівки.

Ключові слова: вогнепальні поранення, механізм поранення, локалізація поранень, поєднані поранення.

Results of the treatment of major vacuum wounds in the united kingdom's operation in the eastern ukraine for the period from 2014 to and quarter of 2019

V.A. Chernyak ${ }^{2}$, V.M. Rogovsky ${ }^{1}$, Y.V. Nahaliuk ${ }^{1}$, Y.Y. Sivash ${ }^{1}$, N.V. Schepetov ${ }^{1}$, K.K. Karpenko ${ }^{1}$

${ }^{1}$ National Military Medical Clinical Center "Main Military Clinical Hospital";

${ }^{2}$ Taras Shevchenko National University of Kyiv, Kyiv

\begin{abstract}
Gunshot wounds of the great vessels remain an urgent and complex area of angiosurgery both in medical and organizational terms. The age category was dominated by patients aged 21 to 3 years (37.3\%) and from 31 to 40 years $(29.4 \%)$. The largest share of injuries occurred in injuries of arteries and veins, accounting for $60.8 \%$. According to the frequency of localization of injuries of the main vessels, injuries of the femoral-popliteal segment prevail - in $76.5 \%$. Gunshot wounds of blood vessels are severe wounds that are often combined with trauma to nerves (23.5\%), bones (37.3\%), bones and nerves $(25.5 \%)$, only soft tissues (13.7\%). In $47 \%$ - the injury was isolated, in the other fighters - combined. The results of treatment in $74.5 \%$ were satisfactory, in $25.5 \%$ - ended with amputation of the limb.
\end{abstract}

Key words: gunshot wounds, wound mechanism, localization of wounds, combined wounds.

Вступ. Локальні озброєні конфлікти в теперішній час і використання сучасних видів вогнепальної зброї призвели до збільшення числа постраждалих від вогнепальної травми, включаючи ураження магістральних судин.

За різними джерелами, вогнепальні пошкодження судин коливаються в межах 2,8-8\% [2,6].

При вивченні частоти локалізації поранень судин, частіше спостерігаються пошкодження артерій стегново-підколінного сегменту у 27,8\% та артерій верхніх кінцівок $(27,4 \%)$, значно рідше - поранення судин шиї, аорти, нижньої порожнистої вени $[1,4]$.

За даними літератури, ізольовані вогнепальні пошкодження артерій спостерігались у 24\% поранених, у 42\% супроводжувалися пораненнями вен, у решти випадків - кісток та нервів. Поєднані пошкодження судин і нервів спостерігались у 42,2\% поранених, судин і кісток - у 28,5\%, пошкодження вен складали $37,7 \%$ від усіх травм судин $[1,4,8]$.

Вогнепальні пошкодження судин $\epsilon$ тяжкою травмою, що часто поєднується 3 ушкодженням інших анатомічних структур. Важливою в практичному аспекті залишається та особливість, що істинна зона пошкодження тканин переважно $\epsilon$ більшою за видимі межі.

Мета дослідження: проаналізувати механізм, характер поранень, включаючи локалізацію та супутне пошкодження, результати лікування та наслідки у пацієнтів з пораненнями магістральних судин у ході операції об'єднаних сил (ООС) на Сході України за період 2014-2019 pp.

Матеріали та методи. Нами було проаналізовано 51 випадок вогнепальних поранень магістральних судин нижніх кінцівок під час проведення ООС на Сході України, котрі проходили лікування у Національному військово-медичному клінічному центрі «ГВКГ» в період з 2014 року по 2019 роки.

Аналізуючи частоту поранень судин по роках було отримано такі дані: за 2014 рік було включено 15 поранень магістральних судин, що становить 29,4\%, у 2015 р. було діагностовано 11 поранень судин $(21,6 \%)$, у 2016 p. - 14 поранень $(27,4 \%)$, у 2017 р. - 3 поранення (5,9\%), у 2018 - 5 (9,8\%), у 2019 - 3 випадки, що відповідає 5,9\% питомої ваги від всіх поранених (діаграма 1). Усі поранені були призивного віку. 


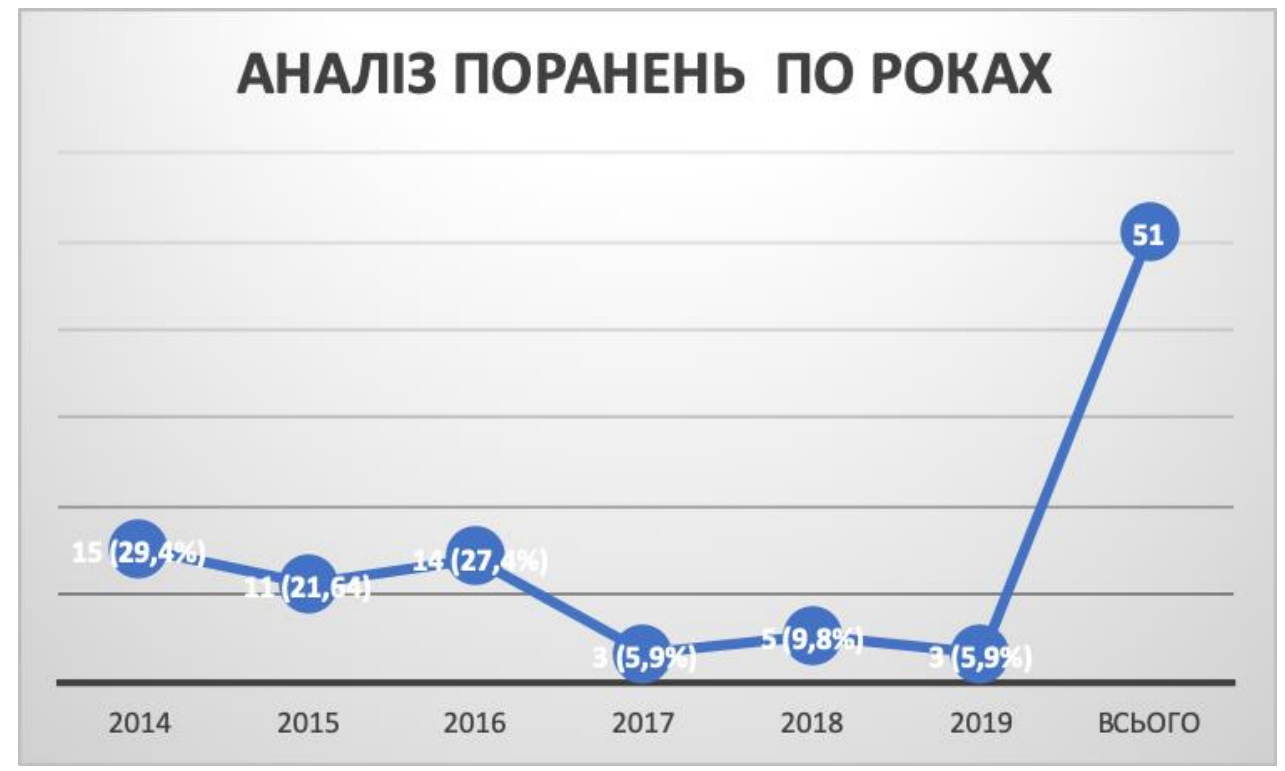

Діаграма 1. Аналіз поранень за роками.

Критеріями включення у дослідження були: 1) військовослужбовці Збройних сил України; 2) пацієнти, котрі отримали нелетальні поранення; 3) пацієнти, які потребували втручання на магістральних судинах; 4) чоловіки.

Критерії виключення складали: 1) усі цивільні особи 3 травмою судин; 2) летальні випадки, що були зареєстровані до евакуації на етап кваліфікованої ангіохірургічної допомоги; 3) жінки.
Результати досліджень та їх обговорення. Аналізуючи вік поранених, ми отримали такі показники: до 20 років було 5 бійців, що становило 9,8\%, від 21 до 30 років - 19 військовослужбовців, що відповідає 37,3\%, від 31 до 40 років було 15 поранених $(29,4 \%)$, від 41 до 50 зареєстровано 10 поранень $(19,6 \%)$ і старше 50 років було 2 військовослужбовці $(3,9 \%)$ (діаграма 2).

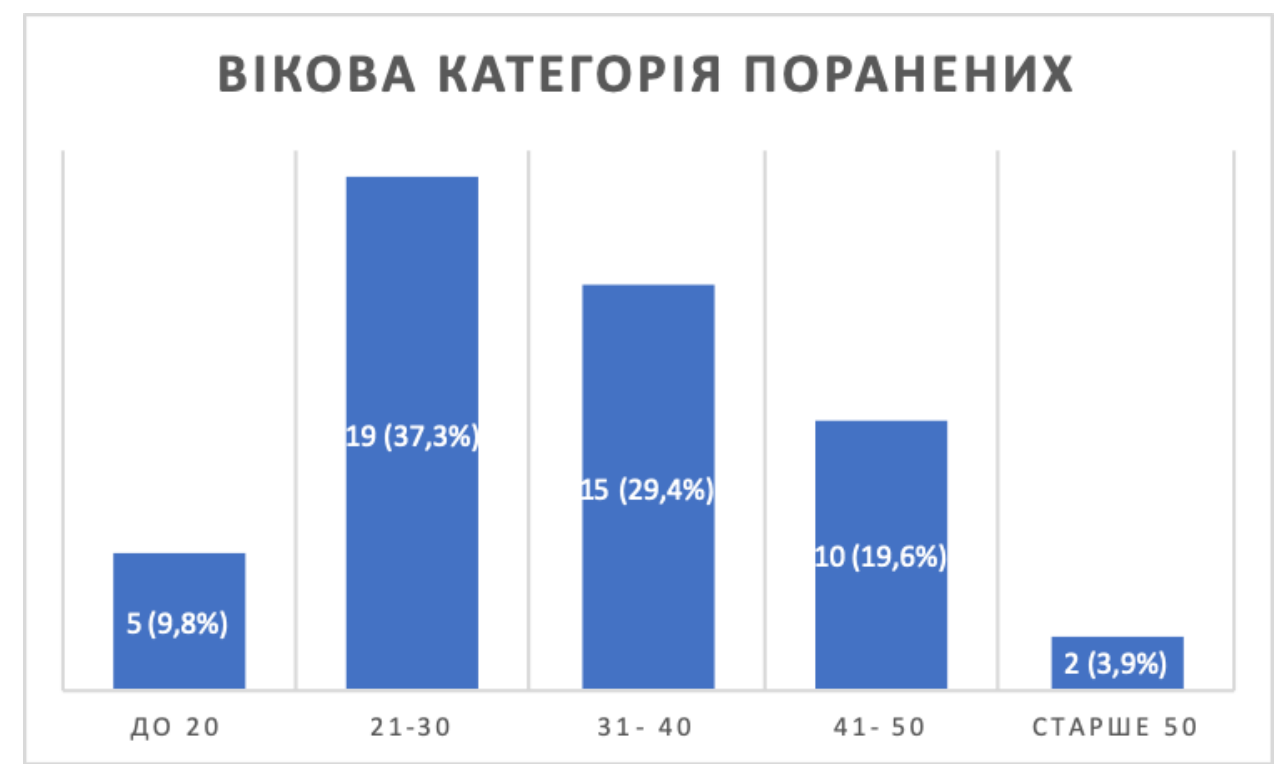

Діаграма 2. Характеристика поранених за віком.

Аналізуючи частоту поранень судин зр роками було отримано такі дані: за 2014 рік було включено 15 поранень магістральних судин, що становить $29,4 \%, 3$ них у віці до 20 років було 3 поранення (20\%), від 21 до 30 років було 11 поранених $(73,3 \%)$, від 31 до 40 років було 1 поранення $(6,7 \%)$. У 2015 році було діагностовано 11 поранень судин $(21,6 \%), 3$ них від 21 до 30 років було 2 поранення (18,2 \%), від 31 до 40 років було 7 поранень $(63,6 \%)$, від 41 до 50 років 2 поранення $(18,2 \%)$. У 2016 році було зареєстровано 14 поранень $(27,4 \%), 3$ них у віці від 21 до 30 років було 5 поранень $(35,7 \%)$, від 31 до 40 років було 2 поранення $(14,3 \%)$, від 41 до 50 років - 5 поранень $(35,7 \%)$ і старше 51 року - 2 поранення $(14,3 \%)$. У 2017 році було 3 поранення (5,9\%), 3 них 2 пора- 
нення у віці до 20 років $(66,7 \%)$ і 1 поранення від 31 до 40 років (33,3\%). У 2018 році було 5 поранень $(9,8 \%)$, з них 1 у віці від 21 до 30 років (20\%), та по 2 у віці від 31 до 40 років (40\%) та від 41 до 50 років (40\%). У 2019 було 3 випадки, що відповідає 5,9\% питомої ваги від всіх поранених, 3 них від 31 до 40 років було 2 поранення $(66,7 \%)$ та 1 поранення від 41 до 50 років $(33,3 \%)$.
Із 51 випадків 45 поранень було бойових, що становить 88,2 \% та 6 поранень небойових, що відповідає $11,8 \%$. 3 них 1 було у віці до 20 років $(16,7 \%)$, по 2 у віці від 21 до 30 років $(33,3 \%)$ та від 31 до 40 років $(33,3 \%)$ і ще 1 небойове поранення у бійця від 41 до 50 років $(16,7 \%)$ (діаграма 3).

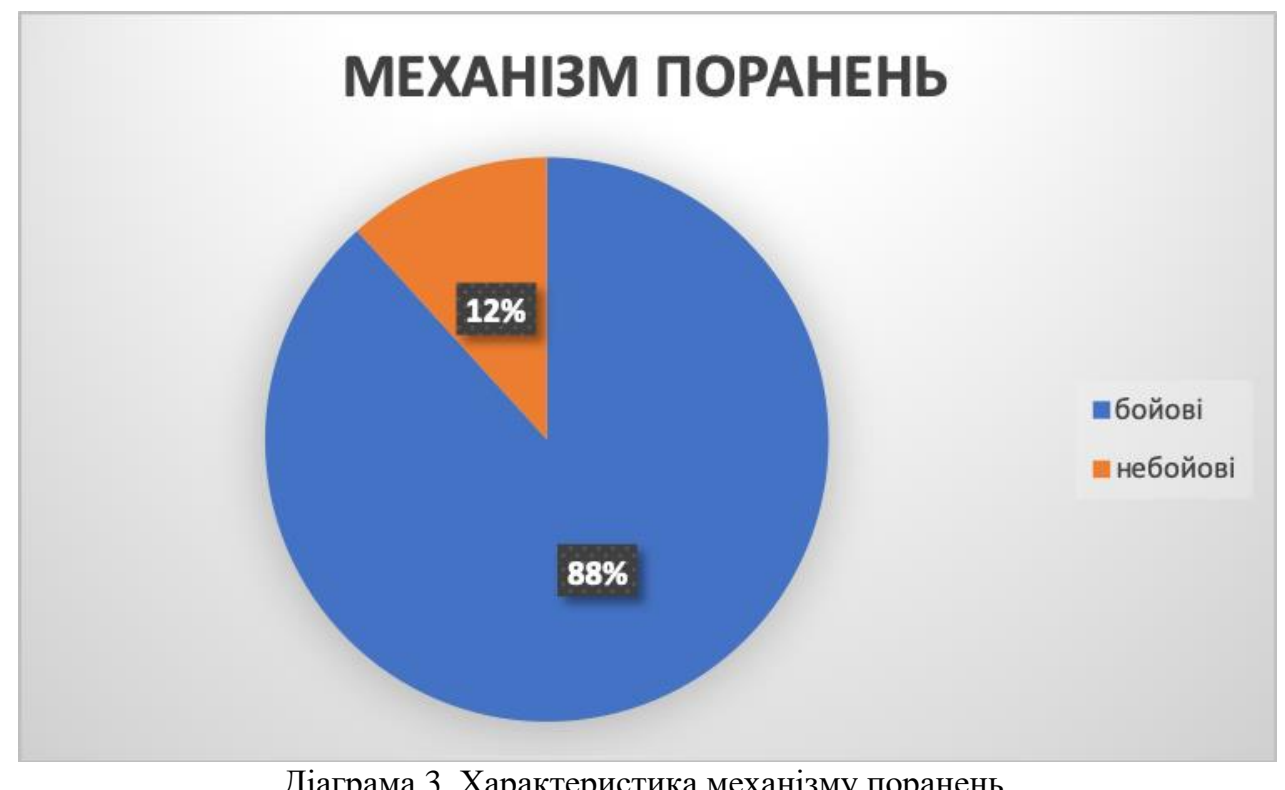

Досліджуючи розподіл поранень магістральних судин за локалізацією, були отримані такі показники. У 39 випадків було поранення стегново-підколінного сегменту (76,5 \%), у 11 пора- нених гомілкового сегменту $(21,6 \%)$ та в 1 випадку $(1,9 \%)$ спостерігалось поранення стегновопідколінного та гомілкового сегменту (діаграма 4).

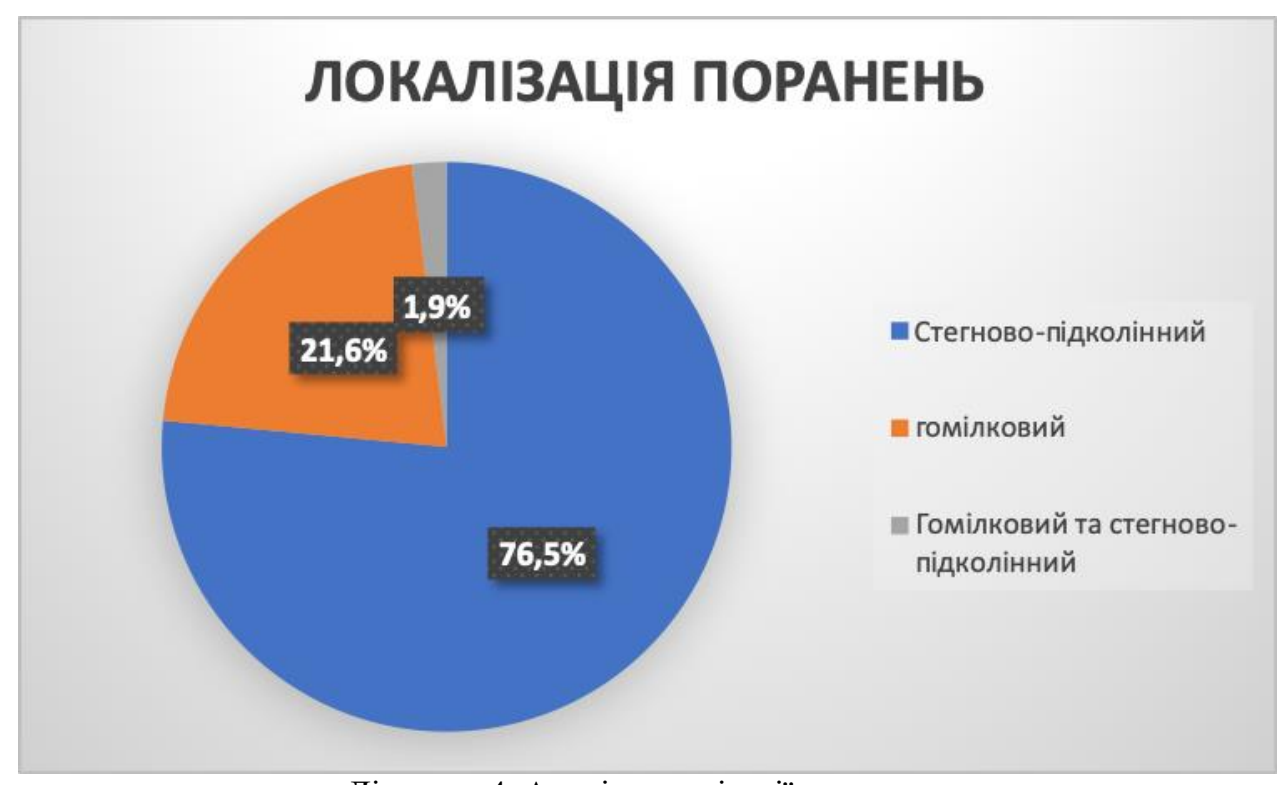

Діаграма 4. Аналіз локалізації поранень.

При чому у віці до 20 років у 4 випадків було поранення стегново-підколінного сегменту (80\%) та у 1 випадку (20 \%) поранення гомілкового сегменту. У віці від 21 до 30 років у 13 випадків було поранення стегново-підколінного сегменту $(68,4 \%)$, у 5 випадків гомілкового $(26,3 \%)$ та зафіксовано 1 випадок поранення стегново-підколінного та гомілкового сегменту, що становить 5,3\%. У віці від 31 до 40 років було 13 поранень стегново-підколінного сегмен- 
ту $(86,7 \%), 2$ поранення гомілкового сегменту $(13,3 \%)$. У віці від 41 до 50 років було 7 поранень стегново-підколінного сегменту $(70 \%)$ та 3 поранення гомілкового сегменту (30\%). У 2 па- цієнтів, старших 51 року, було зафіксовано поранення стегново-підколінного сегменту, що становило $100 \%$ у своїй віковій категорії (діаграма 5).

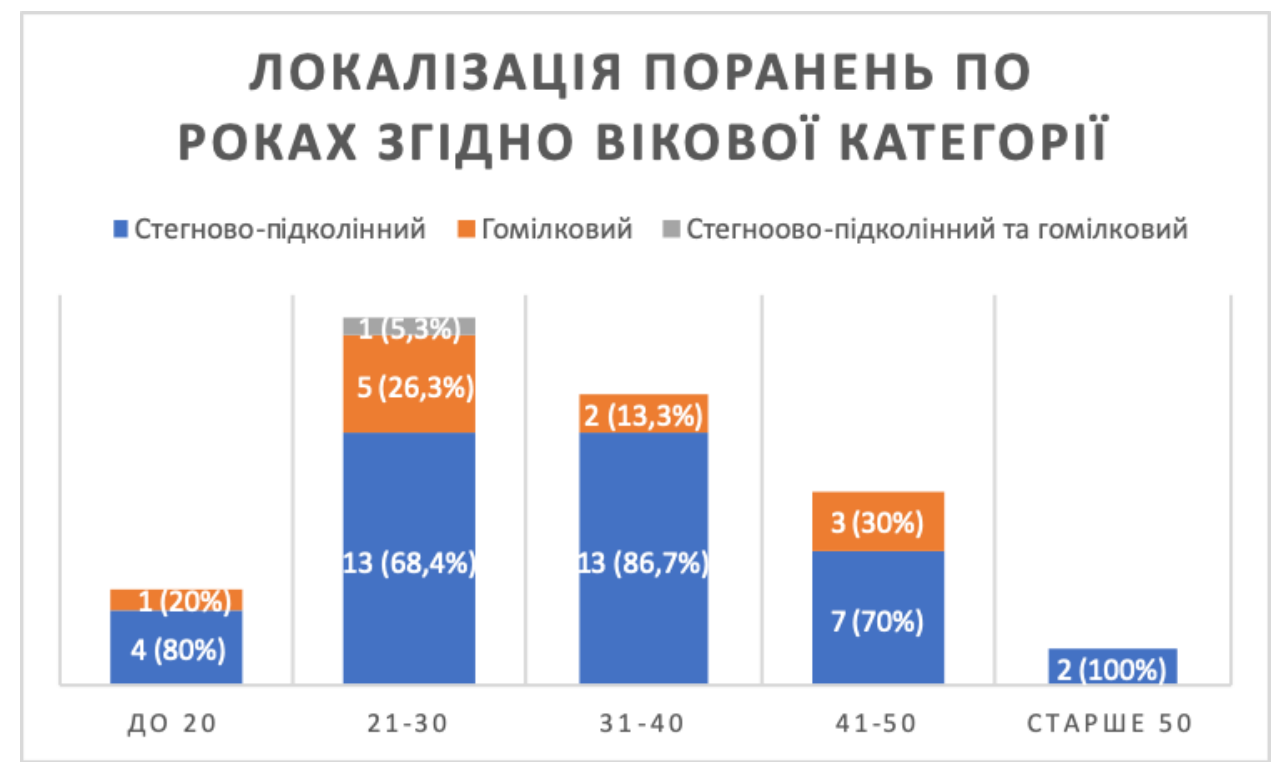

Діаграма 5. Характеристика локалізації поранень залежно від вікової групи.

Таким чином, вказані дані щодо частоти локалізації вогнепальних поранень судин збігаються 3 літературними даними, отриманими при аналізі даного питання під час проведення інших бойових конфліктів у світі.
Аналізуючи вид ураженої судини у 20 випадків $(39,2 \%)$ було поранено лише артерію i у 31 випадку $(60,8 \%)$ - артерію та вену (діаграма 6).

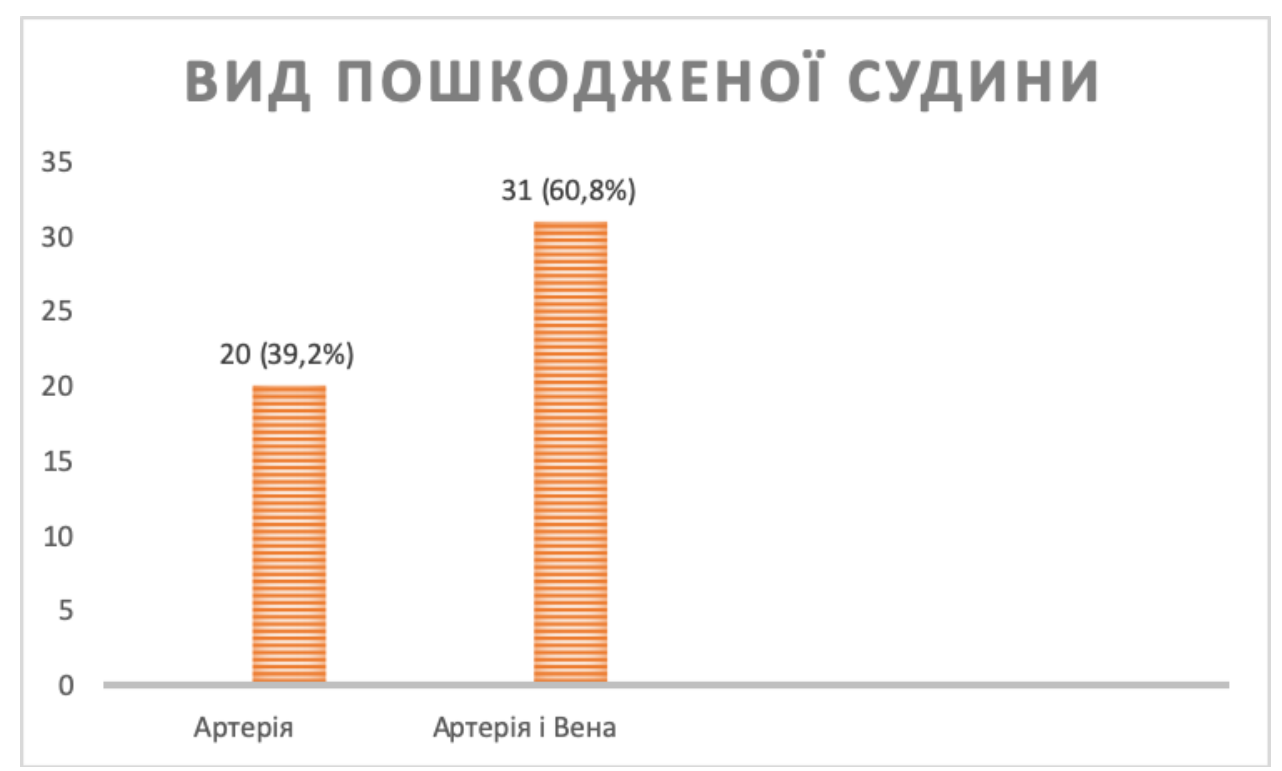

Діаграма 6. Характеристика виду ураженої судини.

Із них у віці до 20 років поранення артерії спостерігалось у 3 випадків (60\%) та у 2 - поранення артерії та вени (40\%). У віці від 21 до 30 років у 6 випадків було поранення артерії $(31,6 \%)$ та у 13 поранення артерії та вени $(68,4 \%)$. У віці від 31 до 40 років було 6 пора- нень артерій (40\%) та 9 поранень артерії та вени $(60 \%)$. Від 41 до 50 років виявлено поранення артерії у 3 бійців (30\%) та у 7 поранення i артерії, і вени (70\%). У віковій групі від 51 року і старше відзначено 2 поранення артерій, що відповідає 100\% (діаграма 7). 


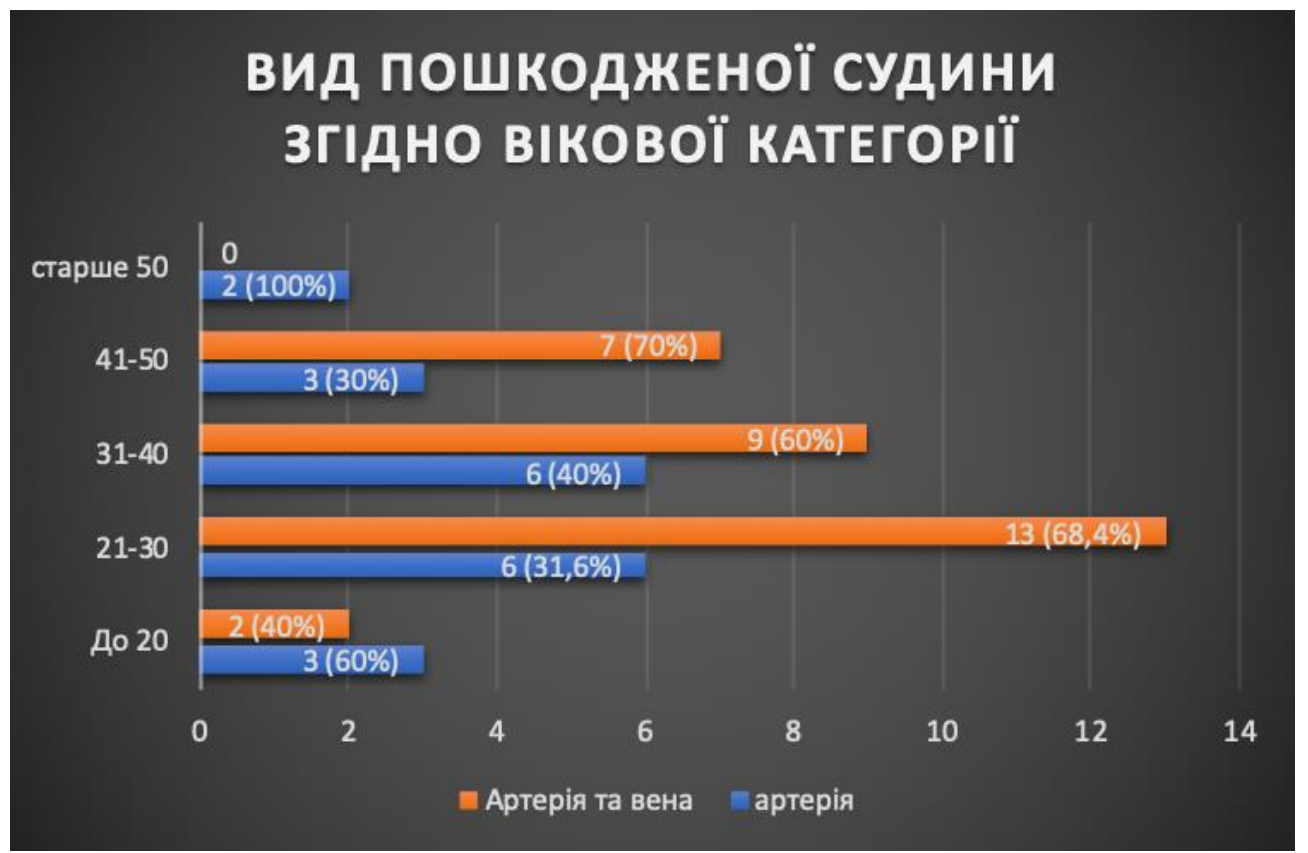

Діаграма 7. Характеристика виду пошкодженої судини залежно від вікової групи.

Аналізуючи частоту та характеристику супутнього пошкодження судин були отримані такі результати. У 7 випадків поранення виявлені поранення тільки судин і м'яких тканин $(13,7 \%)$, у 19 випадків - поєднання поранення 3 кісткою, що становить 37,3\%, у 12 випадків - 3 нервом, що відповідає 23,5\%, та у 13 випадків - залучення і кістки, і нерва $(25,5 \%)$ (діаграма 8$)$.

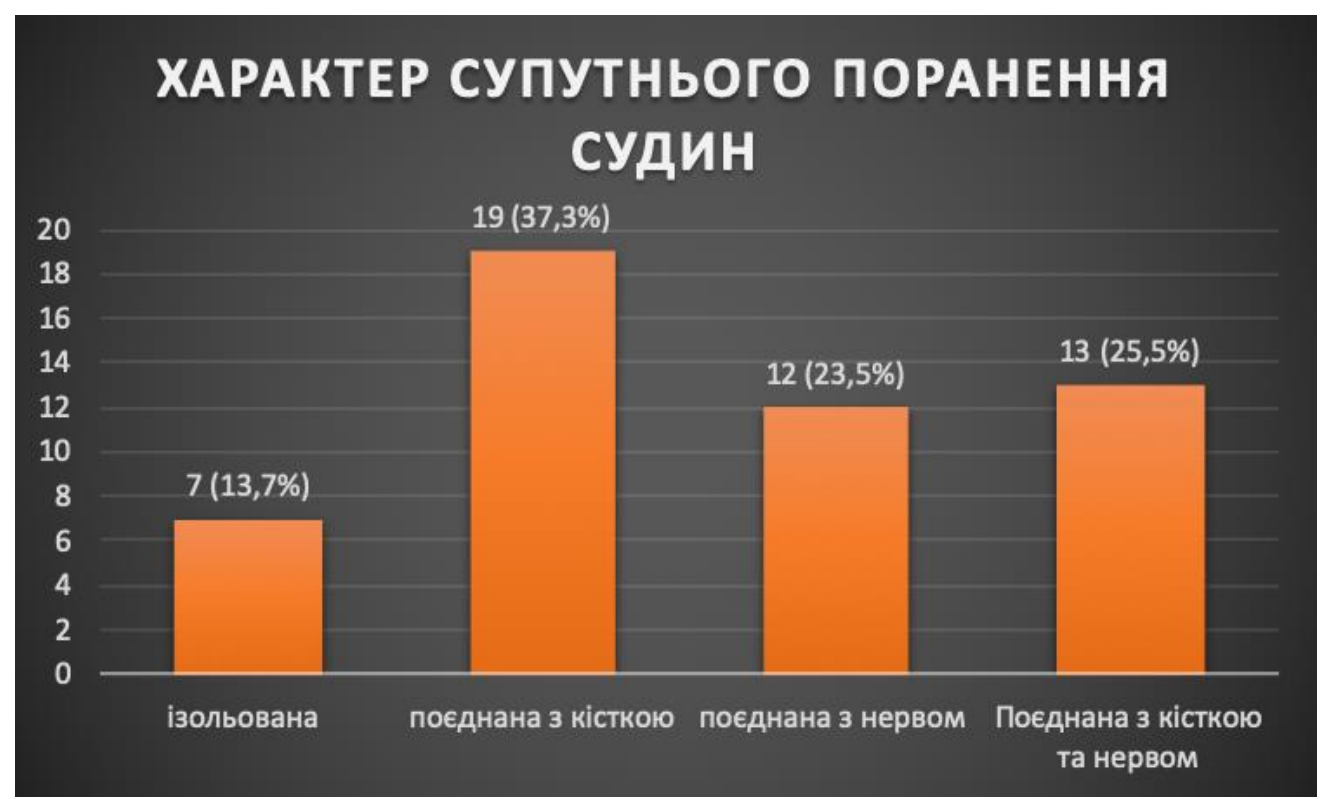

Діаграма 8. Характеристика супутнього поранення судин.

Аналізуючи поєднання травми за віковими групами було отримано наступні дані. У віці до 20 років у 2 бійців було поранення кістки (40\%), у 1 нерва (20\%), у 2 - поранення кістки та нерва (40\%). У віці від 21 до 30 років у 4 було поранення кістки $(21 \%)$, у 6 - нерва $(31,6 \%)$, у 6 - кістки і нерва $(31,6 \%)$, у 3 - лише поранення судин i м'яких тканин, що становить $15,8 \%$ у своїй віковій групі. У віці від 31 до 40 років у 6 військовослужбовців було поранення кістки (40\%), у 3 - нерва
(20\%), у 4 - кістки та нерва $(26,7 \%)$, у 2 - тільки поранення судин та м'яких тканин $(13,3 \%)$. У віковій групі від 41 до 50 років у 6 випадків виявлено поранення кістки (60\%), у 2 - нерва (20\%), у 1 кістки та нерва (10\%), ще в 1 випадку було поранення тільки судин і м'яких тканин (10\%). У військовослужбовців у віці 51 року і старше в 1 було поранення кістки $(50$ \%) і ще в 1 - поранення тільки судин і м'яких тканин, що відповідає 50 \% у своїй віковій групі (діаграма 9). 


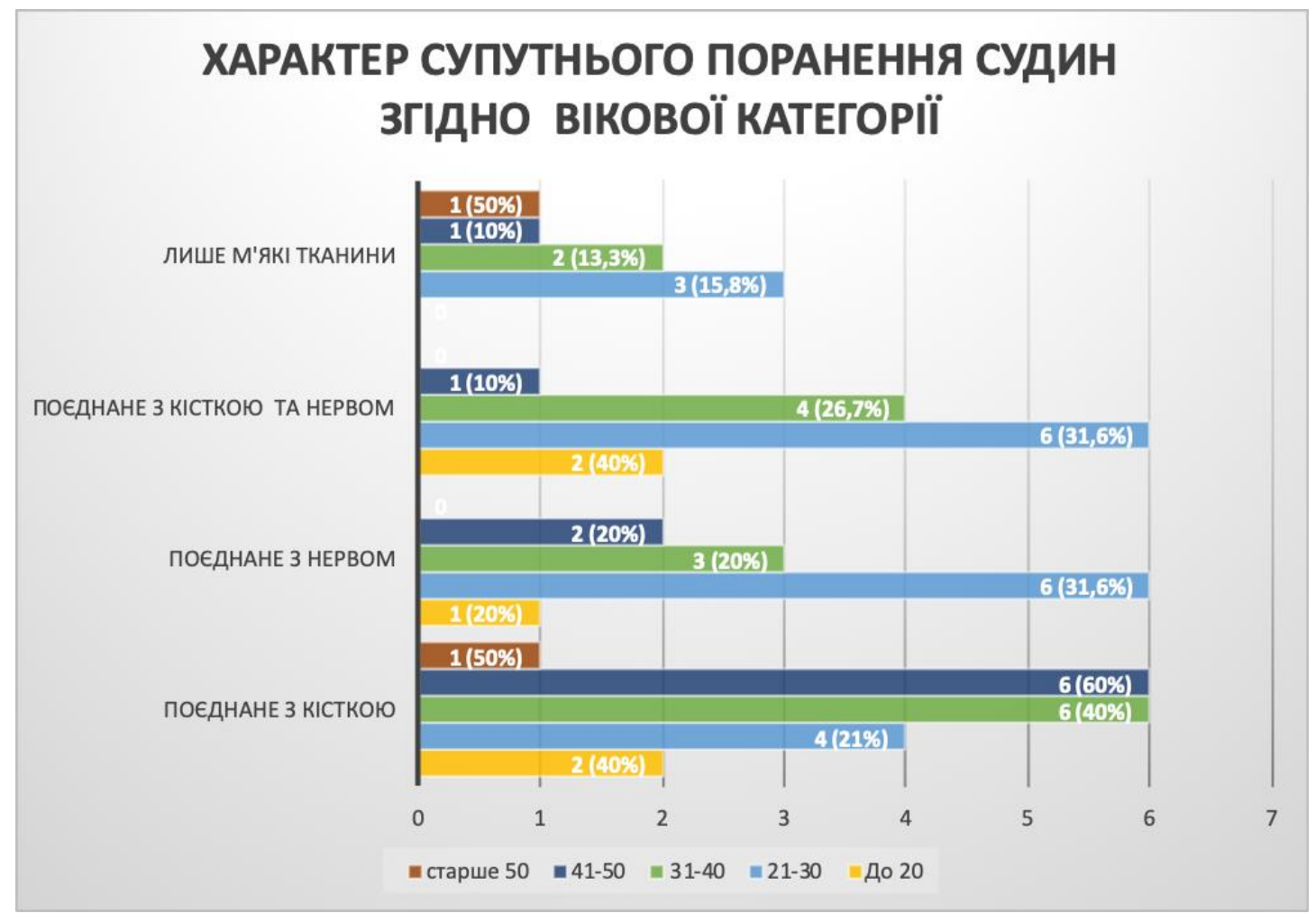

Діаграма 9. Характеристика супутнього поранення залежно від вікової групи.

У 24 випадках поранення було ізольованим, що становить 47,1\%, у 27 - множинним, що відповідає $53 \%$ і розподілилися таким чином: у 13 бійців було поранення нижніх та верхніх кінцівок або обох нижніх $(25,5 \%)$, у 1 випадку - поранення голови та шиї (2\%), у 2 - органів грудної клітки (3,9\%), у 2 органів черевної порожнин $(3,9 \%)$, у 9 бійців було зафіксовано поранення 3 та більше анатомічних зон $(17,6 \%)$ (діаграма 10).

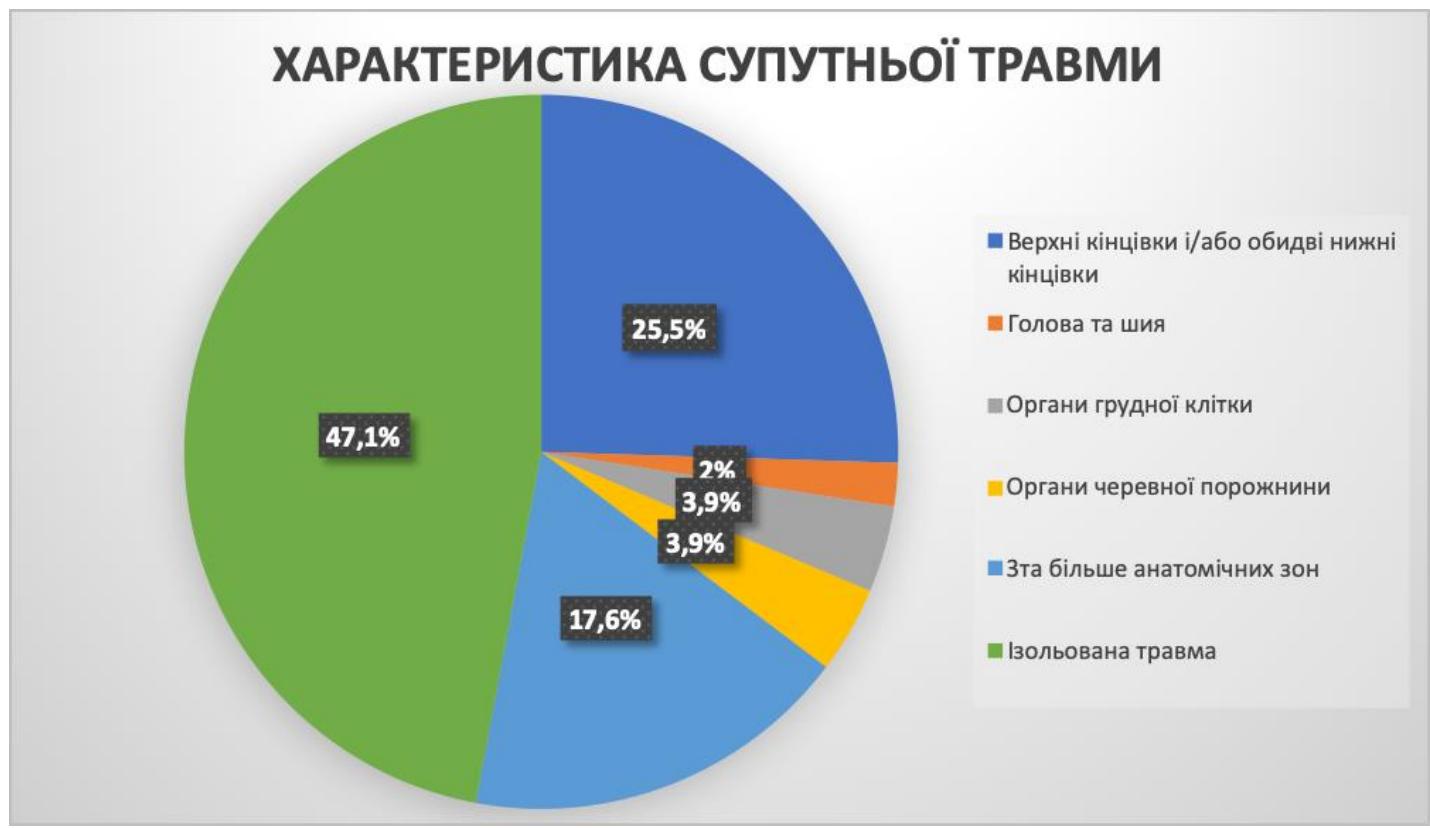

Діаграма 10. Характеристика супутнього поранення судин.

Аналізуючи множинну травму за віковими групами було отримано такі дані. У віці до 20 років у 2 поранених травма було ізольованою (40\%), у 1 було пошкодження верхніх або обох нижніх кінцівок (20\%), у 1 випадку - поранення органів грудної клітки (20\%), у 1 випадку (20\%) поранення 3 та більше анатомічних зон. У віці від 21 до 30 років у 7 бійців травма була ізольованою $(36,8 \%)$, по 1 випадку - поранення органів грудної клітки $(5,3 \%)$ та органів черевної порожнини 
(5,3\%), у 4 мало місце поранення 3 та більше анатомічних зон (21\%), поранення верхніх або обох нижніх кінцівок мало місце у 6 випадках (31,6\%). У віці від 31 до 40 років у 9 військовослужбовців поранення було ізольованим (60\%), у 4 зафіксовано поранення верхніх або обох нижніх кінцівок $(26,6 \%)$, у 1 - поранення органів черевної порожнини $(6,7 \%)$, у 1 - поранення 3 та більше анатомічних зон (6,7\%). У віковій групі від 41 до 50 років у 5 випадків поранення було ізольованим (50\%), по 2 випадки було з поранення верхніх або обох нижніх кінцівок (20\%) та поранення 3 і більше анатомічних зон (20\%), в 1 випадку (10\%) було поранення органів черевної порожнини. У віці від 51 року і старше в 1 випадку поранення було ізольованим, що відповідає $50 \%$ у своїй віковій групі, і ще 1 - поранення 3 та більше анатомічних зон (50\%) (діаграма 11).

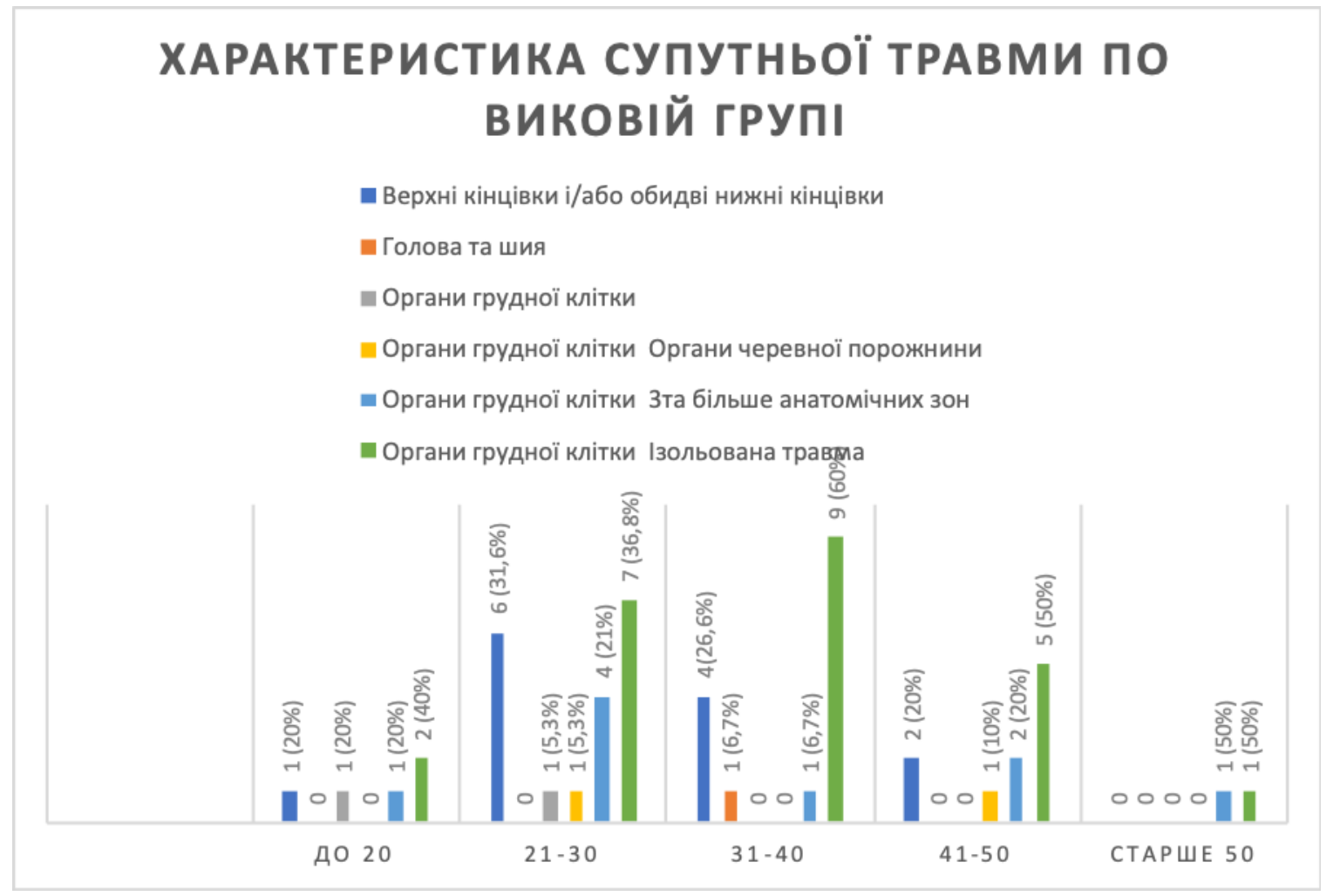

Діаграма 11. Аналіз супутньої травми залежно від вікової групи.

Аналізуючи результати лікування у 38 випадків було зафіксовано задовільний результат, що становить 74,5\% і в 13 - лікування закінчилось виконанням ампутації $(25,5 \%)$ (діаграма 12 ).

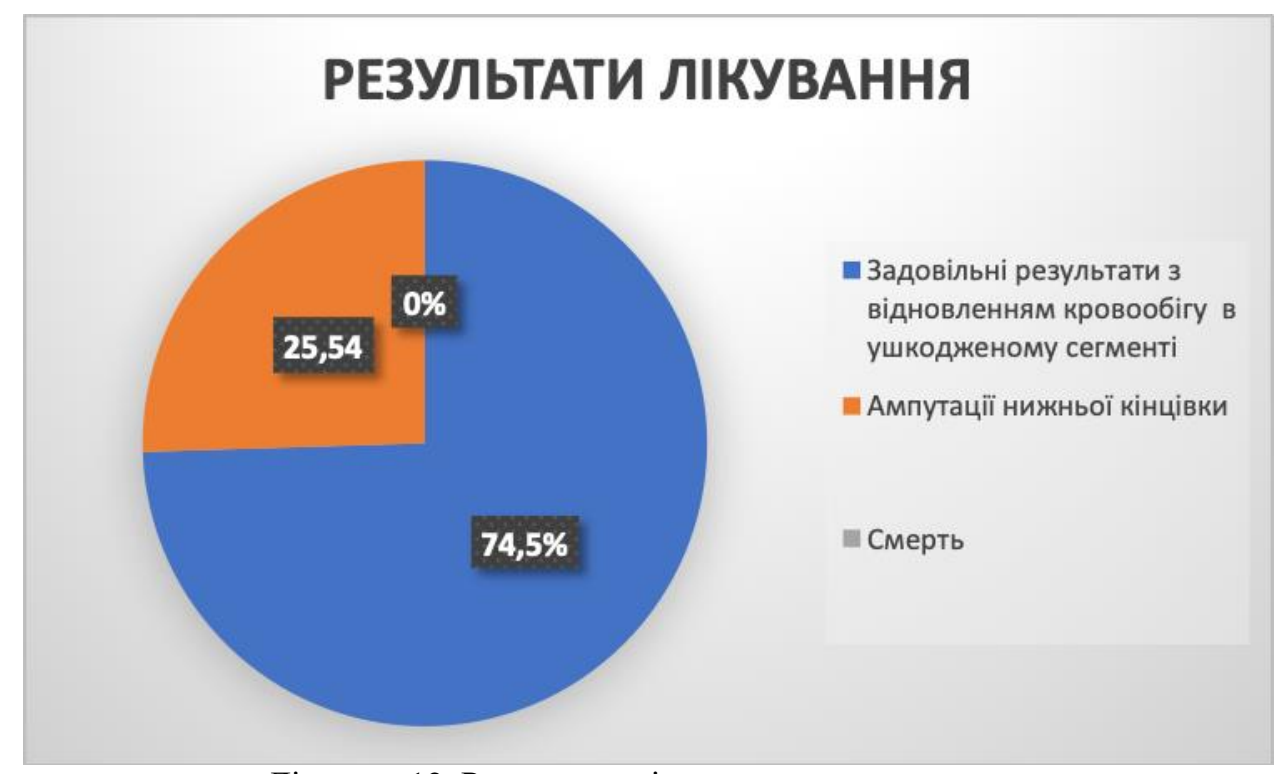

Діаграма 12. Результати лікування поранень судин. 
Причому у віці до 20 років ампутація була в 1 пораненого, що відповідає 7,7 \% усіх ампутацій, у віці від 21 до 30 років у 7 поранених
$(53,8 \%)$, від 31 до 40 років у 3 випадках $(23,1 \%)$, від 41 до 50 років у 2 бійців $(15,4 \%)$ (діаграма 13).

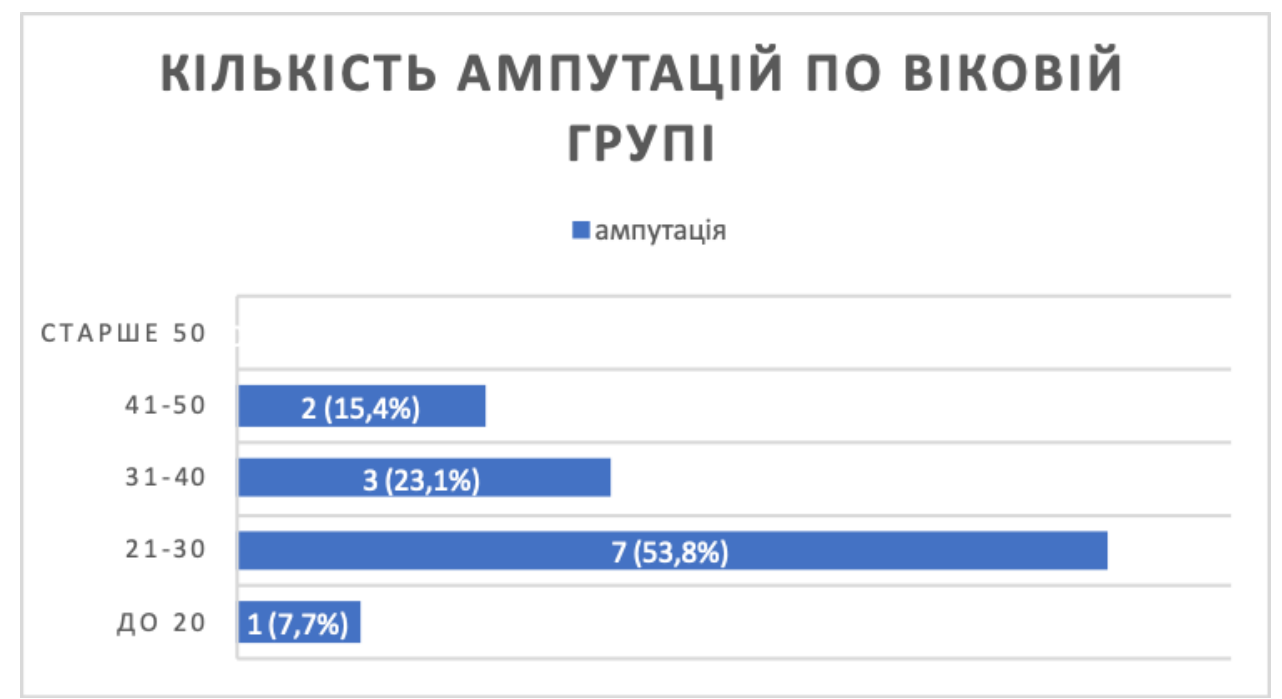

Діаграма 13. Аналіз виконаних ампутацій залежно від вікової групи.

Аналізуючи результати лікування за віковими групами пацієнтів, були отримані такі дані. У віці до 20 років у 4 поранених були задовільні результати лікування (80\%) та у 1 - ампутація (20\%). У віці від 21 до 30 років у 12 випадків результати були задовільні $(63,2 \%)$ та у 7 - виконано ампутацію (36,8\%). У віковій групі від 31 до 40 років у 12 бійців результати були задовільними (80\%) та у 3 - виконано ампутацію (20\%). У військовослужбовців віку 41-50 років у 8 результати були задовільними (80\%) і у 2 - виконано ампутацію (20\%). У військовослужбовців старше 51 року були відзначені тільки задовільні результати, що відповідає $100 \%$ у своїй віковій групі.
Проводячи аналіз віддалених наслідків у 22 $(43,1 \%)$ військовослужбовців ускладнень не виявлено, у 3 бійців $(5,9 \%)$ було утворення артеріовенозної нориці, в 1 з них супроводжувалась формуванням венозної недостатності, у 3 (5,9\%) - утворення хибної аневризми, в 1 з них - тромбоз, в 1 випадку був тромбоз із відновленням кровотоку $(2 \%)$, у $9(17,7 \%)$ - формування артеріальної недостатності та у 7 $(13,7 \%)$ - тромбоз та формування артеріальної недостатності в результаті, у 4 (7,8\%) бійців зафіксовано арозивну кровотечу, при чому в 2 з них було формування венозної недостатності в результаті, у 2 відзначено формування хронічної венозної недостатності $(3,9 \%)$ (діаграма 14$)$.

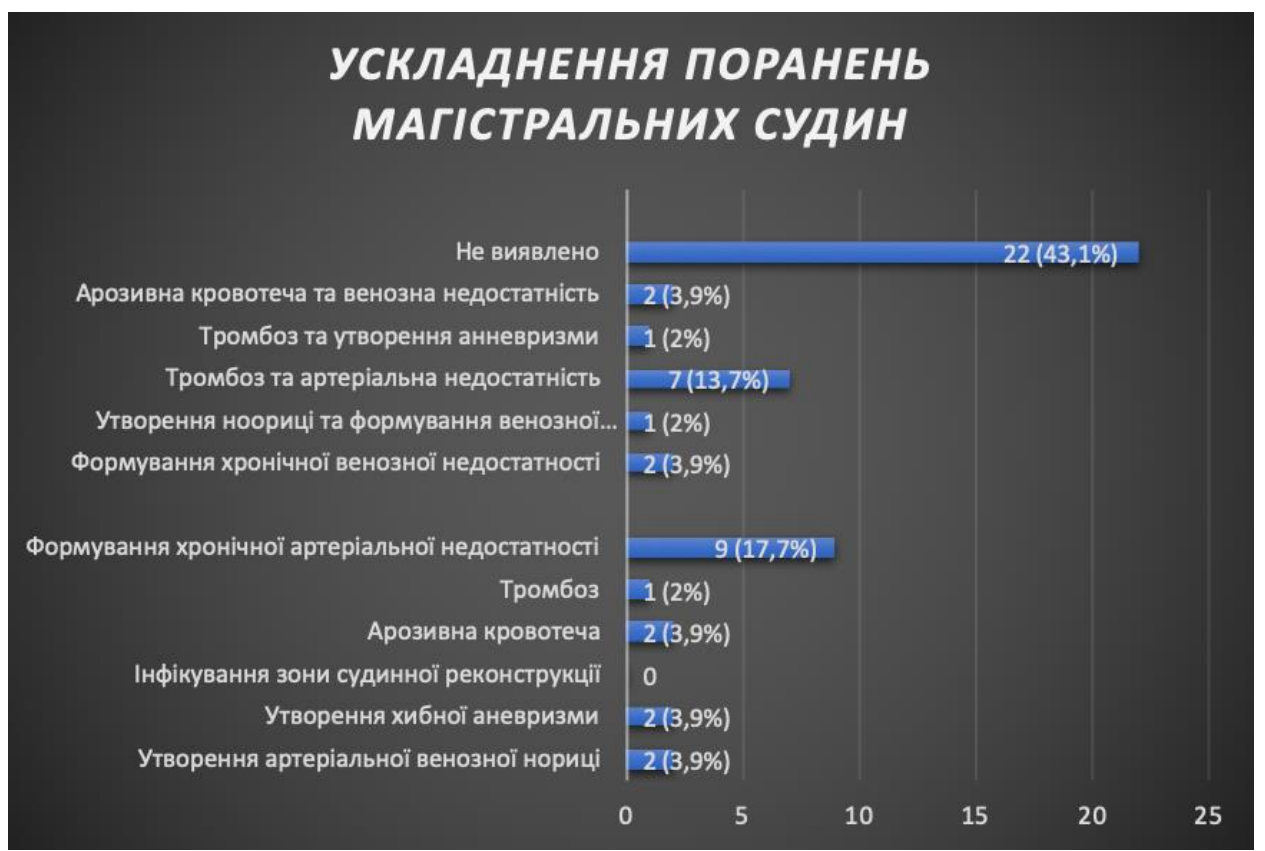

Діаграма 14. Характеристика ускладнень поранень магістральних судин нижніх кінцівок. 
Аналізуючи частоту виникнення ускладнень за віковими групами, було отримано такі дані. У віці до 20 років ускладнень не виявлено у 4 військовослужбовців (80\%) та в 1 відзначено формування хронічної артеріальної недостатності (20\%). У віці від 21 до 30 років у 7 бійців ускладнень не виникало $(36,8 \%)$, у 1 - артеріо-венозна нориця $(5,3 \%)$, у 2 - арозивна кровотеча та формування венозної недостатності (10,5\%), у 3 - формування хронічної артеріальної недостатності $(15,8 \%)$, у 5 - тромбоз і формування артеріальної недостатності $(26,3 \%)$, у 1 - хронічна венозна недостатність $(5,3 \%)$. У віці від 31 до 40 років у 6 (40\%) - ускладнення не зареєстровані, у 3 (20\%) - формування хронічної артеріальної недостатності, у 1 - утворення хибної аневризми (6,7\%), у 1 - арозивна кровотеча $(6,6 \%)$, у 1 - тромбоз з відновленням кровотоку в результаті $(6,6 \%)$, у 1 - утворення нориці та формування венозної недостатності $(6,7 \%)$, у 1 - тромбоз та формування аневризми $(6,7 \%)$, у 1 - тромбоз та формування артеріальної недостатності (6,7\%). У віковій групі від 41 до 50 років у 5 - ускладнень не було $(50 \%)$, у 1 - утворення артеріо-венозної нориці (10\%), у 1 - арозивна кровотеча (10\%), у 1 формування хронічної артеріальної недостатності (10\%), у 1 - тромбоз та формування артеріальної недостатності (10\%), у 1 - формування хронічної венозної недостатності (10\%). У віковій категорії від 51 року і старше у 1 бійця було утворення хибної аневризми (50\%) та в 1 - формування хронічної артеріальної недостатності (50\%).

Проводячи аналіз виконаних операцій, отримали такі показники. Всього у 51 пораненого було виконано 513 операцій, 3 них на магістральних судинах - 77 (15\%), ампутацій та реампутацій $14(2,7 \%)$, інших - $422(82,3 \%)$. Судинний шов було накладено у 10 випадках $(1,9 \%)$, аутовенозне протезування - у 19 (3,7\%), аллопротезування - у 16 бійців $(3,1 \%)$, перев'язка судин - у 19 випадках $(3,7 \%)$, операції з приводу артеріовенозної нориці - у $3(0,6 \%)$, при чому в 1 з них виконано стентування, операції $з$ приводу посттравматичних аневризм - у 3 військовослужбовців $(0,6 \%)$, тромбектомія - у 4 (0,8\%), ендоваскулярні втручання - у $1(0,2 \%)$, ампутація кінцівки - у 13 бійців $(2,6 \%)$ та в 13 них - реампутація $(0,2 \%)$, ПХО - 349 (68\%), MOC - $12(2,3 \%)$, торакоцентез та дренування по Бюлау - $5(0,97 \%)$, торакоскопія та видалення гематоми - $2(0,4 \%)$, первинний шов нервового стовбуру - $1(0,2 \%)$, пластика вени - $1(0,2 \%)$, аутодермопластика - у 8 випадках $(1,6 \%)$, тимчасовий шунт було накладено у 2 бійців $(0,4 \%)$, АЗФ - у 15 (2,9\%), фасціотомія - у 15 (2,9\%), видалення стороннього тіла $-3(0,6 \%)$, накладення сигмостоми - $1(0,2 \%)$, видалення сигмостоми - $1(0,2 \%)$, лапаротомія та дренування - $5(0,97 \%)$, спленектомія - $1(0,2 \%)$, геміколектомія - $1(0,2 \%)$, ендолазерокоагуляція лівого ока - $1(0,2 \%)$. Проводячи аналіз кратності операцій на магістральних судинах у кожного 3 поранених були отримані різні дані. Для зупинки кровотеч із точкових пункцій них дефектів магістральних судин застосовували спеціально для цього розроблений електрокоагуляційний пристрій-монополяр, який застосовувався під контролем УЗ-датчика у місці дефекта судини. Для медикаментозної зупинки кровотеч у периопераційному періоді застосувували транексамову кислоту, яка входить в ініціативу Patient Blood Management. В Україні препарат випускається під назвою Сангера. Для корегування анемічних явищ, окрім гемотрансфузій, застосовували препарат Суфер ${ }^{\circledR}$ - розчин для в/в ін'єкцій 3 діючою речовиною 20 мг заліза у вигляді заліза (III) гідроксид сахарозного комплексу. Випускаєтся у формі ампул по 100 мг (5 мл) №5 і у флаконах 200 мг (10 мл) + 0,9\% NaCl-Солювен 100 мл. Безпосередньо перед введенням препарат розводили в $0,9 \%$ розчині натрію хлориду. Для проведення провідникової анестезії перевагу віддавали місцевим анестетикам зі швидким початком дії і тривалою операційною анестезією. Найпопулярніший місцевий анестетик бупівакаїн вітчизняного виробництва (Лонгокаїн). Медикаментозна підтримка хірургічних втручань була такою: базова терапія + Реосорбілакт 400 мл/доба, Латрен 400 мл/доба, Тівортін 100 мл/доба (схема терапії «Тріо»). У гострому періоді застосовувалася рестриктивна стратегія інфузійної терапії (за Chappell D. із співавт.) з використанням кристалоїдів і багатокомпонентного полііонного колоїдно-гіперосмолярного розчину Гекотон як колоїдного плазмоекспандера. Препарат Гекотон вводили в об'ємі 5 мл/кг 3 метою профілактики гемодинамічних порушень перед виконанням анестезії, потім - перед затисканням магістральних судин (у дозі 3 мл/кг) і для попередження синдрому ішемії-реперфузії після декліпіювання артерії і вени. 3 метою профілактики інфекційних ускладнень у післяопераційному періоді використовували ЛЕФЛОЦИН (левофлоксацин) - антибактеріальний препарат широкого спектру дій, фторхинолонового ряду з вираженим бактерицидним ефектом. ЛЕФЛОЦИН виявився активним щодо широкого спектру грамнегативних та грампозитивних мікроорганізмів, анаеробів, Helicobacter pylori та атипових форм, таких як Micoplasma, Chlamidia, Legionella. ЛЕФЛОЦИН призначався пораненим внутрішньовенно крапельно по 250-500 мг (50-100 мл) 1 раз на добу для профілактики післяопераційних ускладнень, курсом 5-7 діб. У особливо важких випадках використовували вітчизняний Грандазол - комбінований антибактеріальний препарат, до складу якого входить левофлоксацина гемігідрат і орнидазол у флаконах для внутрішньовенного введення по 100 і 200 мл. Використовували також препарат ТІВОРЕЛЬ (4,2 г аргініну гідрохлорид + 2,0 г L-карнітину) тим бійцям, у яких підозрювали поєднану хронічну ішемію міокарда. Препарат вводили внутрішньовенно краплинно зі швидкістю 10 крапель за хвилину протягом перших 10-15 хв, потім 
швидкість введення можна збільшити до 30 крапель за хвилину. Добова доза препарату - 100 мл розчину. У комплекс засобів детоксикації залучали препарати вітчизняного виробництва: ксилат, реосорбілакт, сорбілакт. Реосорбілакт - комплексний інфузійнний розчин, на основі багатоатомного спирту та натрію лактату. Реосорбілакт застосовувався у передопераційній підготовці в дозі 400 мл (6-7 мл/кг), крапельно, одноразово та після операції, з розрахунку 8-10 мл/кг на одну інфузію, крапельно, через день. У хворих, в яких діагностували хронічну венозну недостатність після поранень магістральних вен, обов'язковим було застосування таблетованого препарату цикло-3-форт. Антисептиками вибору були Декасан і бетадін, для обробки шкіри - Горостен.

Висновки. Із огляду на значну частку та важкість вогнепальних поранень судин серед причин травмування бійців на полі бою основне завдання практичних лікарів сьогодні - це налагодження чіткого алгоритму надання ефективної медичної допомоги постраждалим із цим видом травм, спрямованого на порятунок життя від гострої крововтрати, запобігання тяжкій інвалідизації (збереження кінцівки), а також лікування ускладнень i наслідків судинної травми на всіх етапах медичної евакуації.

Для надання ефективної допомоги постраждалим необхідно забезпечити лікування та профілактику гострої ішемії кінцівки, що виникає у хворих 3 тяжким геморагічним і травматичним шоком, a також створення системи спеціалізованої хірургічної допомоги і реабілітації в центрах відновного лікування.

Інформація про конфлікт інтересів. Автори заявляють про відсутність конфлікту інтересів при виконанні наукового дослідження та підготовці даної статті.

Інформація про фінансування. Автори гарантують, що вони не отримували жодних винагород у будь-якій формі, здатних вплинути на результати роботи.

\section{Особистий внесок кожного автора у виконання роботи:}

Черняк В.А. - розробка концепції і дизайну дослідження, аналіз отриманих даних, редагування, статистична обробка даних.

Роговський В.М. - збір матеріалу дослідження, розробка дизайну дослідження, аналіз отриманих даних.

Нагалюк Ю.В. - збір матеріалу дослідження, аналіз отриманих даних, підготовка тексту статті.

Сіваш Ю.Ю. - збір матеріалу дослідження, аналіз отриманих даних, підготовка тексту статті.

Щепетов М.В. - збір матеріалу дослідження, аналіз отриманих даних.

Карпенко К.К. - збір матеріалу дослідження, аналіз отриманих даних.

Список використаної літератури

1. Fisher G.W. Acute arterial ibjuries treated by the United states army medical service in Vietnam 19651966//J.Trauma. 1967. Vol.7, №6. P.844-855.

2. Fry W.J. Is arteriography necessary in the management of vascular trauma of extremities // Surgery. 1978. Vol.84, №4. P. 557-562.

3. Lavenson G.S., Rich N.M., Baugh J.N. Value of ultrasonic flow detector in the management of peripheral vascular disease // Amer. J. Surg, 1970. Vol.12. №4. P. 522-526.

4. Levitsky S. Vascular trauma in Vietnam battle causcaltion // Ann. Surg. 1968. Vol. 168, №2. P. 831-836.

5. Learmont J. Injuries of blood vessels // History of the second war Surgery. London, 1953. P. 538-544.

6. Love L., Braun T. Arteriography of peripheral vascular trauma // Am. J. Roengenol. 1968. Vol .192, №2. P. 431-440.

7. Makins G.N. Injuries to the blood vessels: History of the great War Medical services // Surgery of the war. London, 1992. Vol. 2. P. 170-206.

8. Rich N.M., Spencer F.C. Vascular trauma. Philadelphia etc.: Saunders Co., 1978. 610 p.

\section{Стаття надійшла до редакції: 4.02.2020 р.}

